\title{
POLIGAMI PERSPEKTIF ULAMA BANJAR
}

\author{
Abdul Helim \\ Institut Agama Islam Negeri Palangka Raya, Indonesia \\ E-mail: helim1377@gmail.com
}

\begin{abstract}
This article attempts to discuss the views of Banjarese 'ulama and the legal method used in responding to the issue of polygamy. The Banjarese ulama interviewed are nine. This study reveals the existence of different opinions among the Banjarese ulama. There are many ulama who accept polygamy, the minority being not too rigid in terms of conditions for polygamy, while the majority emphasize rigid conditions. However, there are ulama who reject polygamy due to various considerations and recent conditions. The desire to polygamy can be tolerated, but the conditions are required. The difference of opinions between the Banjarese ulama cannot be separated from the method of Islamic law used in understanding this phenomenon. If related to usü alfigh, most views of the Banjarese ulama with regard to polygamy can be concludedas using the method of istibsan and dhari'ah.
\end{abstract}

Keywords: Polygamy; Banjarese ulama; legal method.

\section{Pendahuluan}

Selama ini masyarakat Banjar atau bahkan dari kalangan ulama Banjar sering diidentikkan dengan poligami. Di samping poligami diatur dalam agama, ada pula semacam anekdot yang tidak asing di kalangan masyarakat Banjar, yaitu:

Beristri satu baru belajar

Beristri dua adalab wajar

Beristri tiga adalah terpelajar

Beristri empat baru disebut urang Banjar. ${ }^{1}$

${ }^{1}$ Ungkapan di atas khususnya pada bagian ketiga dipopulerkan oleh Ustadz Arifin Ilham. Dalam salah satu referensi disebutkan bahwa bagian ketiga adalah "beristri tiga kurang ajar". Sepengetahuan penulis ungkapan yang lebih familiar adalah "beristri tiga kurang wajar". Dikatakan demikian karena kata "kurang ajar" adalah lebih cenderung dimaknai sebagai sumpah serapah yang ditujukan kepada orang yang dibenci. Adapun ungkapan "kurang wajar" walaupun sangat terbuka dapat dimaknai secara negatif tetapi ia juga dapat bermakna jumlah istri yang dimiliki 
Anekdot di atas menurut sebagian kalangan cukup menyudutkan perempuan atau pun masyarakat Banjar yang tidak berpoligami, tetapi sebagian lainnya ada yang menanggapinya sebagai guyonan yang cukup ditanggapi melalui senyum simpul. Terlepas dari permasalahan ini, poligami adalah sebuah topik yang menarik untuk dibahas karena cukup menyedot perhatian berbagai kalangan. Sejak ditetapkan poligami di dalam Islam, sejak itu pula muncul beragam pendapat dengan berbagai interpretasi yang masih terjadi sampai sekarang. Ada yang pro dan ada pula yang kontra terhadap poligami, sehingga perbedaan pendapat pun tidak dapat dihindarkan. Namun apapun itu, poligami merupakan sebuah kenyataan dalam kehidupan masyarakat dari dahulu hingga sekarang.

Kenyataan ini tidak hanya terjadi pada masyarakat Banjar, tetapi juga terjadi di masyarakat-masyarakat Islam lainnya bahkan ditemukan beberapa kajian tentang poligami di beberapa daerah Indonesia, di antaranya ada juga yang mengkritik poligami para kiai. ${ }^{2}$ Ketika poligami dianggap sebagai suatu masalah maka menjadi masalah pula bagi seluruh masyarakat Islam secara keseluruhan. Ia dikatakan bermasalah karena orang-orang yang melakukan poligami datang dari berbagai kalangan baik dari kalangan awam atau pun dari kalangan orang-orang yang memiliki pengetahuan agama. Di sisi lain juga karena adanya dorongan yang sangat kuat untuk berpoligami sehingga di antara pelaku poligami itu ada yang tidak memiliki kekuatan ekonomi bahkan terkesan memaksakan diri untuk melakukannya. Hal ini hampir dipastikan bermasalah, bahkan walaupun memiliki kekuatan ekonomi tetapi jika tidak diiringi dengan kemampuan untuk

masih tanggung sehingga perlu ditambah lagi sampai empat orang. Pada jumlah yang ke empat itulah baru dikatakan sebagai urang (orang) Banjar. Sebagai perbandingan tentang anekdot itu dapat dilihat dalam Wardatun Nadhiroh, "Poligami Tuan Guru: Analisis atas Budaya Perempuan 'Basurung' di Banjar" dalam http://idr.uin-antasari.ac.id/6427/

2 Bukti bahwa poligami tidak hanya terjadi di masyarakat Banjar Kalimantan Selatan dapat dilihat dalam artikel yang dikemukakan di sini bahwa poligami juga merupakan persoalan di daerah-daerah lain, bahkan poligami dilakukan oleh orangorang dari berbagai kalangan dengan beranekaragam status sosialnya. Lihat Rini Rinawati, "Dramaturgi Poligami", Mediator, Vol. 7, No. 1 (Juni 2006), 147-148. Lihat pula tentang poligami para kiai yang diklaim sebagai bagian dari status ke-kiai-an mereka dan sebagai suratan atau garis hidup mereka. Ita Musarrofa, "Poligami: antara Legalitas Formal dan Legalitas Budaya: Studi Kasus Praktik Poligami Kyai Pesantren di Probolinggo Jawa Timur", al-Mawarid: Journal of Islamic Law, Vol. 14 (2005), 203-204. 
memahami aturan hukum poligami maka kehidupan berpoligami yang dijalani pun masih berpotensi mendatangkan masalah. Namun di antara kalangan awam agama ada yang menganggap bahwa penguasaan agama juga tidak memberikan jaminan rumah tangga yang terikat dalam ikatan poligami akan dapat menghadapi berbagai masalah. Hal ini dibuktikan bahwa tidak sedikit di antara pelaku yang menguasai agama juga mengalami kegagalan dalam berpoligami. ${ }^{3}$

Di sisi lainnya, pihak perempuan yang dijadikan sebagai istri kedua, ketiga atau keempat pun berasal dari berbagai latar kehidupan baik secara ekonomi atau pun pendidikan, bahkan ada pula wanita yang berasal dari kehidupan malam. Kehidupan mereka sebagai istri muda secara umum ada yang menjadi lebih baik, tetap seperti sebelumnya dan ada pula yang lebih buruk dari sebelumnya. Bagi mereka yang mendapatkan kehidupan yang lebih baik dari sebelumnya mungkin dapat dikatakan beruntung, seperti yang diperoleh salah seorang perempuan yang mau dinikahi sebagai istri muda di samping mendapatkan materi diberikan pula hadiah berangkat umrah bersama orang tuanya. ${ }^{4}$

Inilah sekelumit fenomena yang diperoleh dari hasil penelusuran yang dilakukan dan sangat memungkinkan masih banyak yang belum terungkap terkait dengan kehidupan poligami. Namun jika menyimak kembali permasalahan yang dikemukakan tampaknya cukup beralasan jika hal tersebut dikaji secara mendalam dan serius. Agar kajian ini dapat dilihat dari berbagai sisi maka diperlukan orang-orang yang memiliki otoritas untuk menanggapi hal tersebut. Orang-orang yang dimaksud adalah para ulama yang di dalam kajian ini hanya dikhususkan kepada ulama Banjar. Pentingnya melibatkan ulama, karena mereka memiliki kekuatan yang dilegitimasi sendiri oleh agama sebagai corong dan penyambung risalah kenabian. ${ }^{5}$ Kendatipun

\footnotetext{
3 Observasi dan Wawancara dengan beberapa sumber tentang poligami di kalangan tertentu masyarakat Muslim Kalimantan Selatan Desember 2015 - Maret 2016.

${ }^{4}$ Ibid.

${ }^{5}$ Lihat hadīth Nabi tentang ulama adalah pewaris Nabi dalam Abū Dāwd al-Shi'ath al-Sijsītānī al-Azdī, Sunan Abì Dāwod, Vol. 4 (Beirut: Dār Ibn Hạam, 1997), 39-40. Ibn Hịbān dan Ḥākim serta selain dari keduanya menyatakan ḥadīth tersebut șaḥị. Lihat 'Abd al-Majīd al-Sawsūh al-Sharfì, al-Ijtihäd al-Jamā' č fì al-Tashri' al-Islämì (Qatar: Wuzārat al-Awqāf li al-Shu'ūn al-Islāmiyah, 1998), 59. Dalam al-Jāmi' al-Ṣahịḥ Imām al-Bukhāri matan ḥadīth dimaksud merupakan pengantar bab al-Tlm Qabl al-Qawl wa al-'Amal. Lihat Abū 'Abd al-Lāh b. Muḥammad Ismāôil al-Bukhārī, Șaḥị̣ al-Bukhārì, Vol. 1 (Beirut-Damaskus: Dār Ibn Kathīr, 1993), 37.
} 
kedudukan fatwa ulama di Kalimantan Selatan dan daerah-daerah Indonesia lainnya tidak mengikat, tetapi sebagai ulama dipastikan memiliki rasa tanggung jawab untuk membina dan membimbing masyarakat Muslim yang salah satunya adalah menanggapi bahkan mengkaji persoalan-persoalan yang bermunculan.

Ulama Banjar yang dimaksud adalah ulama yang masih hidup di zaman sekarang dengan beberapa kriteria yaitu berasal dari etnis Banjar, bertempat tinggal di Kalimantan Selatan, diakui masyarakat sebagai ulama, sebagai referensi masyarakat bertanya tentang persoalan agama termasuk hukum Islam, menyebarkan ilmunya di salah satu tempat yaitu di Pondok Pesantren yang besar, tertua dan populer di Kalimantan Selatan bahkan di sekitar pulau Kalimantan atau di majelis taklim besar dengan jumlah jemaah terbanyak baik dari laki-laki atau perempuan. Mereka adalah Guru H. Asmuni (Guru Danau), Guru H. Muhammad Bakhiet, ${ }^{7}$ Guru H. Ahmad Zuhdiannor, ${ }^{8}$ Guru H. Husin Naparin, Lc, MA, ${ }^{9}$ Guru H. Supian Surie, Lc, ${ }^{10}$ Guru H. Muhammad Naupal, ${ }^{11}$ Guru H. Zarkasyi Hasbi, Lc, ${ }^{12}$ Guru H. Nursyahid Ramli, Lc, ${ }^{13}$ dan Ustazah Dr. Hj. Habibah Djunaidi, MA. ${ }^{14}$ Permasalahan yang dikaji terkait dengan pendapat ulama Banjar di atas terhadap hukum poligami yang terjadi di zaman

${ }^{6}$ Pimpinan empat Pondok Pesantren (Darul Aman di Babirik, Hidayatus Shibyan di Danau Panggang, Darur Rahman di Tanjung, Ar-Raudhah di Jaro) dan tiga Majelis Taklim (Darul Aman di Danau Panggang, Bitin dan Mabuun Tabalong) Kabupaten Hulu Sungai Utara Kalimantan Selatan.

7 Pimpinan Pondok Pesantren (Nurul Muhibbin di Kitun Barabai) dan dua Majelis Taklim (Nurul Muhibbin di Kitun Barabai dan di Balangan) Kabupaten Hulu Sungai Tengah dan Kabupaten Paringin Kalimantan Selatan.

8 Pimpinan Majlis Taklim di Mesjid Sabilal Muhtadin, di lingkungan tempat tinggal dan di Mesjid Jami Banjarmasin Kalimantan Selatan.

${ }^{9}$ Majelis Taklim dan pimpinan Pondok Pesantren Rasyidiyah Khalidiyah (RAKHA) di Amuntai Kabupaten Hulu Sungai Utara Kalimantan Selatan.

10 Salah seorang unsur pimpinan Pondok Pesantren Ibnul Amin Pamangkih Kabupaten Hulu Sungai Tengah Kalimantan Selatan.

11 Pimpinan Pondok Pesantren Darussalam Martapura Kabupaten Banjar Kalimantan Selatan.

12 Pimpinan Pondok Pesantren Darul Hijrah Cindai Alus Martapura Kabupaten Banjar Kalimantan Selatan.

13 Yayasan Pondok Pesantren Al-Falah Putera dan Puteri di Landasan Ulin Banjar Baru Kalimantan Selatan.

14 Pimpinan Pondok Pesantren Al-Falah Puteri di Landasan Ulin Banjar Baru Kalimantan Selatan. 
sekarang dan metode hukum yang digunakan ulama Banjar dalam menanggapi persoalan poligami.

\section{Hukum Berpoligami menurut Ulama Banjar}

Poligami dapat diartikan beristri lebih dari satu orang sampai batas maksimal sebanyak empat orang istri. Dalam mazhab Ahl al-Sunnah tidak dibolehkan beristri melebihi dari empat orang istri dalam satu waktu. Oleh karena itu apabila ingin menambah istri untuk yang kelima maka diharuskan menceraikan salah seorang dari istri yang ada sampai berakhirnya masa idah istri tersebut. ${ }^{15}$

Ulama Banjar menyatakan poligami dibolehkan dalam Islam. Bolehnya berpoligami ini menurut mereka didasarkan petunjuk alQur'ān, 4: 3 yang secara tegas membolehkan poligami seperti yang tertulis sebagai berikut:

$$
\begin{aligned}
& \text { وإن خفتم ألا تقسطوا فن اليتامى فانكحوا ماطاب لكم من النساء مثنى وثلث ورباع، فإن خفتم ألاّ الكال } \\
& \text { تعدلوا فواحدة أو ماملكت أيمنكم، ذلك أدنى ألاّ تعولوا. }
\end{aligned}
$$

Poligami menurut Guru Zarkasyi adalah sebagai solusi bagi masyarakat Islam, ${ }^{16}$ dan Guru Bakhiet pun menyatakan tidak dibolehkan mempertanyakan kembali ayat-ayat al-Qur'ān yang telah disebutkan secara jelas dan rinci. ${ }^{17}$ Guru Supian mengatakan hal serupa, bahkan menurutnya jika dilihat dari teks ayat tersebut di atas adalah kebolehan berpoligami sekaligus dua, tiga dan empat orang istri. ${ }^{18}$ Menurut Guru Supian orang yang tidak berani berpoligami termasuk orang yang penakut. Hal ini dipahaminya dari potongan ayat fa-in khiftum an là ta'dilū fa-wähidah yang maksudnya jika takut tidak bisa berbuat adil maka cukup satu istri. Artinya, orang yang merasa khawatir tidak bisa berbuat adil adalah orang penakut, karena kehidupan berpoligami baik hubungannya dengan istri pertama dan istri-istri yang lainnya baru dilakukan dan diketahui sesudah melakukan praktik poligami, bukan diprediksi pada waktu sebelumnya. ${ }^{19}$ Oleh karena itu tambah Guru Supian, istri harus rida yang disertai dengan niat ibadah untuk menerima takdir tersebut dan suami pun berniat untuk menjalankan sunnah Rasul. Apabila ada

\footnotetext{
15 Wahbah al-Zuhaylī, al-Figh al-Islāmì wa Adillatuh, Vol. 7 (Damaskus-Suriah: Dār alFikr, 1985), 165.

${ }^{16}$ Guru Zarkasyi Hasbi, Wawancara, Cindai Alus-Martapura, 11 Desember 2015.

${ }_{17}$ Guru Muhammad Bakhiet, Wawancara, Kitun-Barabai, 13 Desember 2015.

${ }^{18}$ Guru Supian Surie, Wawancara, Pamangkih-Barabai, 12 Desember 2015.

${ }^{19} \mathrm{Ibid}$
} 
seorang istri tidak menerima suaminya berpoligami, berarti ia tidak menerima takdir yang mestinya diterima dengan pasrah kepada Allah. ${ }^{20}$

Berkaitan dengan pemikiran beberapa ulama Banjar di atas tampaknya lebih menarik apabila ditanggapi dari pemikiran $\mathrm{M}$. Quraish Shihab tentang kebenaran interpretasi seorang penafsir terhadap ayat-ayat al-Qur'ān. Khususnya berkaitan dengan pernyataan tentang jelasnya al-Qur'ān membolehkan poligami dan tidak dibolehkan mempertanyakan ayat-ayat yang telah jelas tersebut. Menurut Quraish bahwa maksud yang sebenarnya dari teks-teks alQur'ān sebenarnya tidak dapat dijangkau secara pasti, baik yang diucapkan atau pun yang ditulis. Bagi Allah mungkin hanya mengandung satu arti, tetapi bagi pembaca atau pendengar memiliki arti yang relatif, sebaliknya bagi pembaca atau pendengar hanya mengandung satu arti, tetapi bagi Allah mengandung banyak arti. ${ }^{21}$ Pendapat ini menunjukkan bahwa sebaik apapun interpretasi yang disampaikan tetapi yang paling mengetahui maksud sebenarnya secara mutlak terhadap sebuah teks hanya pemilik teks yakni Allah, sementara pembaca atau pendengar (manusia) hanya dapat mencapai pengetahuan yang relatif atau mendekati pada kebenaran yang dimaksud.

Begitu juga dengan ayat poligami yang sangat mungkin diinterpretasikan kembali karena sebagai teks al-Qur'ān tentu sangat terbuka untuk dibaca dan dilakukan pembacaan ulang untuk setiap masa. Terlebih lagi menyangkut poligami yang berkaitan erat dengan kehidupan dan martabat manusia, tentu diperlukan pemahamanpemahaman yang membumi sesuai dengan kehidupan manusia di setiap generasi.

Memulai langkah ini tampaknya sangat penting memperhatikan kembali bahwa al-Qur'ān, 4: 3 tentang poligami berkaitan erat dengan ayat sebelumnya yaitu al-Qur'ān, 4: 2 tentang perintah kepada orang yang mengelola harta anak yatim (wali). Harta tersebut diserahkan kembali ketika mereka berusia balig. Selama dalam pengelolaannya, wali dilarang menukar harta itu atau memakannya (menggunakan) yang dapat merugikan anak yatim itu. ${ }^{22}$ Pada ayat selanjutnya yaitu al-

\footnotetext{
${ }^{20}$ Ibid.

${ }^{21}$ M. Quraish Shihab, Membumikan Al-Quran (Bandung: Mizan, 1996), 138.

22 Aḥmad Muṣtafā al-Marāghī, Tafsìr al-Marāghì, Vol. 4 (Mesir: al-Muṣtafā al-Bāb alHalabī, 1946), 178 dan 180.
} 
Qur'ān, 4: 3 disebutkan bahwa wali ini rupanya menyukai harta anak yatim itu dan menyukai pula kecantikannya sehingga berencana ingin menikahinya. Namun karena tidak adil memberikan mahar kepada anak yatim ini setidaknya sama dengan perempuan setingkatnya atau lebih besar, maka wali pun dilarang menikahi perempuan yatim itu, kecuali dapat berbuat adil kepada mereka dan bersedia memberikan mahar sesuai dengan kebiasaan yang berlaku pada waktu itu. Apabila ketentuan ini tidak dilakukan maka lebih baik si wali menikahi perempuan lain yang baik-baik sampai empat orang istri. ${ }^{23}$

Jika dipahami secara normatif, diakui bahwa poligami adalah sebagai solusi karena praktik ini sebenarnya mengangkat harkat dan martabat perempuan. Namun perempuan yang dimaksudkan di sini (lebih utama) adalah anak-anak yatim yang belum memiliki kemampuan untuk mandiri. Ayat ini sepertinya juga memberikan isyarat bahwa awalnya poligami hanya untuk anak-anak yatim asalkan si wali adil mengelola harta mereka dan memberikan mahar yang setara kepada mereka seperti perempuan lain. Kesetaraan ini tetap dituntut walaupun anak yatim ini miskin atau kurang menarik. Apabila syarat itu tidak dapat dipenuhi, lebih baik si wali menikah dengan perempuan lain yang bukan yatim dan dari orang yang baik-baik, sehingga si laki-laki tidak bisa berbuat semena-mena karena perempuan ini memiliki keluarga.

Selanjutnya terkait redaksi ayat fa-in kbiftum an là ta'dilü fa-wähịidah. Kata khiftum diartikan meyakini atau melalui prediksi yang kuat, ${ }^{24}$ bahkan melalui perkiraan sekalipun tidak akan dapat berbuat adil juga dapat dibenarkan atau termasuk dalam makna khiftum. ${ }^{25}$ Maksudnya, apabila diyakini atau dominannya tidak dapat berbuat adil atau sudah dapat membaca keadaan diri sendiri walaupun hanya melalui perkiraan bahwa tidak akan dapat berbuat adil maka cukup hanya beristri satu. Oleh karena itu terlihat adanya perbedaan antara orang yang penakut dengan orang yang berpikir secara matang dalam membaca tubuh dan pikiran sendiri agar keputusan untuk melakukan poligami tidak keliru yang berakibat pada diri sendiri dan keluarga lainnya.

${ }^{23}$ Abū Bakr al-Qurțūbī, al-Jāmi‘ li Aḅkām al-Qur'ān, Vol. 6 (Beirut: Mu'assasat alRisālah, 2006), 23-24. Lihat juga Muhammad Ṭāhir b. 'Ashūr, Tafsīr al-Tạ̣rīr wa alTanwìr, Vol. 4 (Tunisia: Dār al-Tūnisiah, 1984), 222-223.

24 al-Qurtūbī, al-Jāmi' li Aḅkēam al-Qur'ān, Vol. 6, 24.

${ }^{25}$ Muhạmmad Rashīd Riḍā, Tafsìr al-Manār, Vol. 4 (Kairo: Dār al-Manār, 1947), 348. 
Di samping itu dipandang penting pula membaca suasana sosiologis orang-orang yang berpoligami sehingga dari pembacaan yang dilakukan dapat membandingkan dengan diri sendiri. Oleh karena itu pendapat yang mengartikan lafal khiftum dalam poligami adalah sebagai orang yang penakut tampaknya tidak tepat karena hanya memahami teks secara lahirnya saja. Selain itu, di dalam berpoligami dipastikan adanya konsekuensi yang harus diterima dan dijalankan secara konsisten, sehingga diperlukan pemikiran yang sangat matang dengan pertimbangan yang maksimal sebelum masuk ke dunia poligami.

Satu hal yang mesti diperhatikan bahwa adanya kekeliruan dari masyarakat dalam memahami ayat poligami. Mereka cenderung hanya melihat bolehnya berpoligami, padahal yang menjadi titik tekan pada ayat poligami adalah adil terhadap istri, sehingga perlakuan adil inilah yang membuat dibolehkannya berpoligami. ${ }^{26}$

\section{Argumen Berpoligami Menurut Ulama Banjar}

Ustazah Habibah mengatakan harus diakui poligami memang ada dalam Islam. Kendatipun pada dasarnya ia tidak mendukung adanya poligami karena tidak sedikit perempuan yang dizalimi dari praktik ini, tetapi sebagai hamba Allah ia juga mengakui dipastikan adanya rahasia-rahasia di balik poligami tersebut sehingga Allah mensyariatkan poligami. ${ }^{27}$

Menurut Guru Zarkasyi poligami merupakan solusi bagi orangorang yang berkebutuhan khusus. Kemampuan fisik dan hasrat setiap orang menurutnya berbeda-beda sehingga ada yang tidak cukup hanya memiliki satu istri melainkan dua sampai batas maksimal empat orang istri. Begitu juga bagi yang memiliki kematangan finansial maka dengan kemampuan tersebut seorang laki-laki dapat mengangkat harkat dan martabat para perempuan. Oleh karena itu, kata ulama ini jumlah istri pada setiap orang tidak dapat disamaratakan terlebih lagi membatasi hanya satu orang istri. Allah lanjutnya mengetahui keadaan hamba-hamba-Nya yang memiliki kebutuhan khusus dalam rumah tangga, sehingga dengan poligami tersebut diharapkan terhindarnya dari perbuatan zina. ${ }^{28}$ Menariknya, walaupun ia menyetujui poligami

\footnotetext{
${ }^{26}$ M. Quraish Shihab, Wawasan Al-Quran (Bandung: Mizan, 1999), 199-200.

${ }^{27}$ Ustazah Habibah Djunaidi, Wawancara, Banjar Baru, 31 Agustus 2016.

${ }^{28}$ Guru Zarkasyi Hasbi, Wawancara., Cindai Alus-Martapura, 11 Desember 2015.
} 
tetapi pada kenyataannya sampai di usia senjanya ia masih monogami dalam rumah tangga.

Guru Naupal juga memiliki pandangan yang sama bahwa poligami diperuntukkan kepada orang-orang yang memiliki kebutuhan khusus dan memiliki alasan lainnya. Hal ini terjadi pada orang yang memiliki hasrat biologis sangat besar sehingga apabila tidak melakukan poligami, sementara istri tidak sanggup melayani yang dapat berakibat tidak terkontrolnya perilaku suami dalam pergaulan. Namun demikian, kata Guru Naupal poligami tidak hanya untuk melampiaskan hawa nafsu saja, tetapi dipastikan adanya persyaratan yang harus dijalankan secara konsisten. ${ }^{29}$

Menurut Ustazah Habibah, agar poligami benar-benar dapat diterima mesti ada alasan-alasan tertentu yang dapat diukur secara objektif. Ulama perempuan Banjar ini melanjutkan misalnya dalam kondisi peperangan yang membuat kaum laki-laki banyak meninggal dunia sehingga tidak berbanding dengan jumlah perempuan atau dalam kondisi istri sama sekali tidak mempunyai keturunan, sementara laki-laki menginginkan keturunan tersebut. Begitu juga kondisi istri yang sakit permanen, sehingga tidak bisa melayani suami. Dalam kondisi sakit seperti itu atau istri dalam keadaan mandul maka suami memiliki alasan untuk beristri lagi, tetapi istri yang ada (istri tua) harus tetap dijaga dan diayomi serta tidak dibiarkan, terlebih lagi dicerai. ${ }^{30}$

Patut dipertimbangkan kembali ungkapan Ibn 'Abd al-Salām yang dikutip al-Bayjūrī bahwa di zaman Nabi Mūsā as dibolehkan menikahi perempuan tanpa batas. Alasannya semata-mata untuk kemaslahatan laki-laki karena pada masa itu Fir'awn telah banyak membunuh anak laki-laki sehingga jumlah laki-laki tidak berbanding dengan perempuan. Di samping itu poligami tidak dibatasi agar kaum perempuan tidak malu karena belum mendapatkan suami. Namun pada zaman Nabi 'İsā as tidak dibolehkan menikahi lebih dari satu orang perempuan. Alasan yang dikemukakan adalah untuk kemaslahatan perempuan karena 'Īsā as dilahirkan tanpa ayah, sehingga wajar jika ajaran 'İsā as lebih memenangkan perempuan. Adapun dalam ajaran Nabi Muhammad memelihara kedua kemaslahatan tersebut yakni dibatasi sampai empat orang istri. ${ }^{31}$

\footnotetext{
${ }^{29}$ Guru Muhammad Naupal, Wawancara, Martapura, 30 Agustus 2016.

${ }^{30}$ Ustazah Habibah Djunaidi, Wawancara, Banjar Baru, 31 Agustus 2016.

31 Ibrāhīm al-Bayjūrī, Hẹshhiyat al-Shaikh Ibrāhìm al-Bayjūrì 'alā Sharḥ al-'Allāmah ibn Qāsim al-Ghazzì 'alà Matn al-Sheikh Abi Shujā', Vol. 2 (Beirut: Dār al-Kutub al'Ilmīyah, 1999), 173-174.
} 
Pendapat di atas menunjukkan bahwa ada atau tidak adanya poligami sepertinya dilihat dari kebutuhan dan penghormatan. Kedua hal ini merupakan satu kesatuan dengan tujuan yang sama yaitu kemaslahatan. Poligami dapat dilakukan karena menjadi kebutuhan primer dan sekaligus sebagai penghormatan pada kaum perempuan. Ketika kebutuhan tersebut sudah tidak ada lagi atau walaupun ada tetapi bukan termasuk kebutuhan primer, terlebih bukan pula sebagai penghormatan, maka bisa jadi poligami tidak dibolehkan.

Selanjutnya, agar alasan-alasan berpoligami ini dapat diukur secara objektif dan memiliki kekuatan hukum, lanjut Ustazah Habibah keinginan poligami ini harus diproses dan mendapat izin dari Pengadilan Agama. ${ }^{32}$ Apabila ketentuan ini tidak ditaati maka pernikahan dengan istri kedua, ketiga dan keempat dihasilkan dari proses yang tidak objektif dan tidak pula memiliki kekuatan hukum. ${ }^{33}$

Di samping beberapa alasan yang dikemukakan ulama Banjar di atas dalam Instruksi Presiden RI Nomor 1 Tahun 1991 tentang Kompilasi Hukum Islam khususnya pada pasal 58 ayat (1), (2) dan (3) bahwa poligami tersebut juga harus mendapatkan persetujuan dari istri dan adanya kepastian dari suami mampu menjamin keperluan hidup istri-istri dan anak-anaknya. Persetujuan istri tersebut dapat diberikan secara tertulis atau pun secara lisan, tetapi tetap pula di dalam persidangan persetujuan tersebut dipertegas kembali secara lisan. Persetujuan ini baru ditiadakan apabila istri-istri tidak dapat diminta persetujuannya atau tidak dapat dihubungi lagi sekurangkurangnya dua tahun atau ada penilaian lain dari hakim. ${ }^{34}$

Namun apabila istri tidak bersedia memberikan persetujuan, sementara suami sangat menginginkan poligami itu maka pengadilan agama dapat menetapkan suatu ketetapan baik disetujui atau pun tidak terkait dengan izin tersebut. Namun semua itu baru diperoleh setelah pengadilan memeriksa dan mendengar keterangan istri yang bersangkutan di persidangan. ${ }^{35}$

Idealnya poligami tidak hanya berdasarkan keinginan suami melainkan juga kehendak dari istri atau istri-istri yang lain, yang

\footnotetext{
32 Ustazah Habibah Djunaidi, Wawancara, Banjar Baru, 31 Agustus 2016.

33 Departemen Agama RI, Bahan Penyuluhan Hukum (Jakarta: Dirjen Bimbingan Masyarakat Islam dan Penyelenggaraan Haji, 2004), 176.

${ }^{34}$ Ibid., 177.

35 Ibid.
} 
artinya diketahui dan disetujui istri. ${ }^{36}$ Oleh karena itu untuk menjaga dan menghormati hak masing-masing suami istri, pengadilan agama juga memberikan kesempatan kepada masing-masing pihak untuk melakukan banding atau kasasi terhadap ketetapan atau keputusan pengadilan agama. ${ }^{37}$

\section{Ketentuan Berpoligami Perspektif Ulama Banjar}

Ulama Banjar menyepakati bahwa poligami sebagaimana alQur'ān, 4: 3 hanya dibolehkan sampai empat orang istri dan diharamkan melebihi dari batas tersebut. Menurut Guru Zarkasyi, Guru Bakhiet, Guru Zuhdi, Guru Supian dan guru-guru lainnya bahwa praktik poligami yang melebihi dari ketentuan adalah termasuk melakukan praktik selir yang diharamkan dalam Islam. Hukum haram melebihi dari ketentuan itu, menurut ulama Banjar yang salah satunya oleh Guru Zarkasyi karena kemampuan orang untuk dapat bertanggung jawab tidak mungkin lebih dari empat istri. Hal ini tidak hanya berkaitan dengan sekedar melampiaskan hawa nafsu, tetapi juga berkaitan dengan tanggung jawab untuk menjamin hidup orang banyak. $^{38}$

Alasan di atas tampak sejalan dengan pemikiran beberapa ulama sebelumnya bahwa poligami ini dibatasi hanya sampai empat orang istri. Di sini disebutkan apabila melebihi dari ketentuan tersebut dikhawatirkan justru akan mendapatkan dosa yang salah satunya akan kesulitan memenuhi hak-hak istri ${ }^{39}$ dan kesulitan pula untuk berlaku adil. ${ }^{40}$ Pada dasarnya memang para suami tidak memiliki kemampuan menunaikan hak-hak para istri secara sempurna. Oleh karena itu apabila merasa khawatir tidak dapat memenuhi syarat-syarat yang ditentukan maka cukup memiliki satu istri ${ }^{41}$ dan apabila tetap dilakukan tanpa mempedulikan adanya hak-hak istri yang akan dilanggar maka haram melakukan poligami. ${ }^{42}$ Adapun huruf wàw pada

\footnotetext{
36 Ali Imron HS, "Menimbang Poligami dalam Hukum Perkawinan", Jurnal Ilmiah Imu Hukum QISTI, Vol. 6, No. 1 (Januari 2012), 135.

${ }^{37}$ Departemen Agama RI, Bahan Penyuluban, 176.

${ }^{38}$ Guru Zarkasyi Hasbi, Wawancara, Cindai Alus-Martapura, 11 Desember 2015.

39 al-Zuhaylī, al-Figh al-Islāmī, Vol. 7, 167. Sayyid Sābiq, Fiqh al-Sunnah, Vol. 2 (Kairo: al-Fatḥ li I'lām al-'Arabī, 1995), 186 dan 189.

${ }^{40}$ Jamāl al-Dīn 'Abd al-Raḥmān b. 'Alī b. Muḥammad al-Jawzī, Zād al-Masìr fì Tlm alTafsìr (Beirut: Dār Ibn Ḥazm, 2002), 255.

${ }^{41}$ al-Zuhaylī, al-Figh al-Islāmì, Vol. 7, 165.

42 Sābiq, Fiqh al-Sunnah, Vol. 2, 186 dan 189.
} 
redaksi mathnā wa thuläth wa rubā' adalah bermakna tafarruq, yaitu pemisahan dan bukan bermakna pengumpulan. Makna pemisahan tersebut maksudnya bahwa poligami dapat dilakukan sebanyak dua orang, bisa tiga orang, bisa juga sampai empat orang istri dan bukan dua ditambah tiga dan ditambah empat yang akhirnya berjumlah sembilan orang istri. ${ }^{43}$

Dalam bahasa lain bahwa poligami hanya dibolehkan mengumpulkan istri sebanyak sampai empat orang dan tidak dibolehkan melebihi dari batas tersebut. Berbeda dengan kelompok Islam yang lain (al-Qāsimìyah) yang memahami huruf wāw itu sebagai pengumpulan sehingga dibolehkan mengumpulkan istri sampai sembilan orang sebagaimana jumlah istri-istri Nabi Muhammad ketika ia wafat berjumlah sembilan orang. ${ }^{44}$ Hal yang sama juga dipahami oleh mazhab al-Zāhirī yang mengartikan mathnā wa thuläth wa rubā' sebagai dua ditambah dua, tiga ditambah tiga dan empat ditambah empat sehingga jumlah keseluruhan menjadi delapan belas orang istri, ${ }^{45}$ bahkan ada pula kelompok lainnya (al-Rāfiḍah) yang membolehkan beristri tanpa batas. ${ }^{46}$

Namun pendapat itu ditolak oleh sejumlah ulama karena merupakan kebodohan yang sangat besar dalam memahami bahasa yang digunakan al-Qur'ān dan hadīth serta bertentangan dengan kesepakatan umat (ulama). ${ }^{47}$ Di samping itu jumlah istri yang maksimal sampai sembilan orang adalah kekhususan yang diberikan kepada Nabi Muhammad yang tidak pernah diberikan kepada orang lain dari umatnya. ${ }^{48}$

Di samping pembatasan jumlah istri, ulama Banjar juga menyepakati adanya syarat yang mesti dilaksanakan. Syarat tersebut adalah berlaku adil terhadap istri. Adil menurut ulama Banjar memberikan bagian yang sama berkaitan dengan sandang, pangan dan papan pada masing-masing istri, sehingga tidak ada yang merasa terzalimi karena perilaku suami, serta adil dalam memberikan giliran

\footnotetext{
43 al-Jawzī, Zād al-Masìr, 255.

44 Abū Zakarīyā Mụ al-Dīn b. Sharf al-Nawawī, Kitāb al-Majmū' Sharḅ alMuhadhdhab li Shayrā̃̄i, Vol. 17 (Jeddah: Maktabat al-Irshād, t.th.), 212.

45 al-Qurtūbī, al-Jāmi' li Aḅkām, Vol. 6, 33.

46 al-Nawawī, Kitāb al-Majmū', Vol. 17, 212.

${ }^{47}$ al-Qurțūbī, al-Jāmi’ li Ạ̣kām, Vol. 6, 33.

48 al-Nawawī, Kitāb al-Majmū', Vol. 17, 212. Ibn al-'Arabī, Aḅkām al-Qur'ān, Vol. 1 (Beirut: Dār al-Kutub al-'Ilmīyah, t.th.), 408.
} 
mabit pada masing-masing istri. Semuanya mendapat giliran yang sama kecuali adanya kesepakatan atau kerelaan dari masing-masing istri.

Berlaku adil dalam menentukan giliran sama pentingnya dengan berlaku adil pada persoalan-persoalan yang telah disebutkan, bahkan Guru Danau mengatakan pemberian giliran tidak hanya dihitung melalui hari melainkan dihitung jam pada masing-masing istri, sehingga tidak ada pula yang merasa terzalimi di antara istri-istri. Ia mengatakan "...adil untuk semua yang ada kaitannya dengan kehidupan rumah tangga, pasti itu. Adil ini tub ai (panggilan untuk anak laki-laki), bukan dihitung hari, tapi jam. Misalnya di satu istri empat jam, maka di istri lain lagi harus empat jam juga. Kalau hitungan hari tidak bisa, harus perjam". ${ }^{49}$

Syarat pembagian waktu (al-qasm) yang dikemukakan Guru Danau tampak berbeda dengan ulama-ulama Banjar lainnya, berbeda pula dengan para ulama lainnya bahkan dengan Rasulullah yang biasanya membagi perhari. Pendapat Guru Danau ini tentu tidak muncul secara tiba-tiba melainkan sudah pasti dihasilkan dari pemikiran yang mendalam, terutama sangat mungkin sekali setelah melihat kondisi orang-orang yang berpoligami di zaman sekarang. Dengan pendapat tersebut Guru Danau tampaknya mengisyaratkan bahwa poligami adalah tanggung jawab dan sekaligus menjadi amanat yang tidak dengan mudahnya dapat dilakukan oleh setiap orang. Oleh karena itu dengan menentukan syarat tersebut (kendatipun masih bisa disepakati masing-masing istri) Guru Danau terlihat berupaya untuk lebih memperketat dan membatasi poligami di kalangan masyarakat Muslim.

Adapun berkaitan dengan perasaan cinta, masing-masing ulama Banjar menyatakan cinta adalah urusan hati dan kedalaman cinta pada masing-masing istri bisa jadi tidak sama, sehingga syarat adil dalam cinta tidak diberlakukan pada orang yang berpoligami. Ulama Banjar juga menyepakati sanksi bagi orang yang tidak adil baik bagi yang monogami atau pun poligami adalah dosa besar karena dipandang berbuat zalim pada para istri. Di samping itu sanksi di hari kiamat kelak pasti akan terjadi dan hal tersebut ditandai dengan sebelah badannya miring. Para ulama Banjar mengemukakan hadīth yang serupa walaupun dengan redaksi yang berbeda tentang sanksi orang

\footnotetext{
${ }^{49}$ Guru Asmuni (Guru Danau), Wawancara, Danau Panggang-Hulu Sungai Utara, 14 Desember 2015.
} 
yang tidak berlaku adil pada istrinya. Di antara redaksi hadìth tersebut adalah:

$$
\text { من كانت له إمرأتان فمال إلى إحداهما جاء يوم القيامة وشقّه مائل } 50
$$

"Barangsiapa yang memiliki dua orang istri kemudian ia cenderung kepada salah seorang di antara keduanya, maka ia akan datang pada hari kiamat dalam keadaan sebelah badannya miring". Berdasarkan gambaran tentang sanksi bagi orang yang tidak adil pada istri, Guru Bakhiet mengatakan apabila seseorang merasa tidak yakin akan mampu berbuat adil pada persoalan-persoalan yang disyaratkan maka haram baginya melakukan poligami walaupun akad nikah yang dilakukan tetap sah. ${ }^{51}$ Pendapat ulama ini tampaknya sejalan dengan pendapat Muhammad 'Abduh yang menyatakan haramnya seseorang berpoligami jika ia sendiri khawatir tidak akan dapat berbuat adil. ${ }^{52}$ Oleh karena itu supaya terlepas dari berbuat zalim dan dosa maka cukup memiliki satu orang istri ${ }^{53}$ yang apabila rasa kekhawatiran ini diabaikan atau tidak dipedulikan tentu akan jatuh kepada yang diharamkan Allah. ${ }^{54}$

\section{Argumen Kontra-Poligami dari Ulama Banjar}

Guru Nursyahid mengatakan dalam memahami ayat poligami mestinya tidak hanya berhenti pada bolehnya melakukan poligami sampai empat orang istri seperti dalam al-Qur'ān, 4: 3, tetapi dapat menyatukan pemahamannya dengan al-Qur'ān, 4: 129 bahwa setiap orang tidak akan pernah dapat berbuat adil walaupun konteks ayat ini terkait dengan memberikan kasih sayang yang tidak disyaratkan dalam poligami. Menurutnya untuk menyikapi al-Qur'ān, 4: 129 tersebut, mesti kembali kepada akhir ayat dari al-Qur'ān, 4: 3 bahwa alternatif yang paling aman adalah hanya memiliki satu orang istri. ${ }^{55}$

Ulama ini sangat meragukan keadilan yang dipaparkan sebelumnya secara normatif dapat dilaksanakan dengan baik sesuai dengan kehendak al-Qur'ān, 4: 3 khususnya pada kondisi sekarang.

50 al-Azdī, Sunan Abì Dāwd, Vol. 2, 415. Dalam redaksi yang berbeda juga terdapat dalam Sunan al-Tirmidhī, Sunan Ibn Mājah dan Sunan al-Dārimī. Salah satunya lihat Abū 'Abd al-Lāh Muḥamad b. Yazīd al-Qazwīnī, Sunan Ibn Mājah, Vol. 1 (t.t.: Dār Ihyā al-Kutub al-'Arabīyah, t.th.), 633.

51 Guru Muhammad Bakhiet, Wawancara, Kitun-Barabai, 13 Desember 2015.

${ }^{52}$ Rid̄ā, Tafsìr al-Manār, Vol. 4, 350.

53 al-Zuhaylī, al-Fiqh al-Islāmi, Vol. 7, 167.

${ }^{54}$ Sābiq, Fiqh al-Sunnah, Vol. 2, 186 dan 189.

55 Guru Nursyahid Ramli, Wawancara, Banjarmasin, 10 Desember 2015. 
Keraguan ini tidak terkecuali pada ulama sekalipun karena menurutnya tidak ada yang dapat menjamin keadilan itu dapat dilaksanakan oleh setiap orang, kecuali hanya pribadi Rasulullah. Menurut Guru Nursyahid hanya Rasulullah yang dijamin dapat berlaku adil. Ia mengatakan:

Yang berpengetahuan aja bisa saja tidak berbuat adil, apalagi yang tidak berpengetahuan, tambah parah lagi, sehingga tidak menjamin kita orang itu adil. Kalau Rasulullah kita berani menjamin, karena beliau mașúm, dijamin oleh Allah bersifat adil. Kalau selain Rasulullah tidak ada yang dijamin oleh Allah. Malah ditekan oleh Allah bahwa kamu tidak bisa berbuat adil, maka kesimpulannya kalau yang dilakukan oleh masyarakat itu salah, berdosa mereka. ${ }^{56}$

Guru Nursyahid menekankan kembali bahwa selain dari Rasulullah siapa pun tidak pernah terlepas dari godaan sehingga selama masih menjadi manusia akan berpotensi berbuat salah atau berlaku tidak adil. ${ }^{57}$ Terlebih lagi lanjutnya, keadaan sekarang sudah jauh berbeda dengan kondisi yang ada pada zaman Rasulullah, sehingga apabila diperhatikan dari orang-orang yang berpoligami sebenarnya tidak sedikit berperilaku lebih banyak menimbulkan kemudaratan. ${ }^{58}$

Pada kenyataannya, poligami tidak luput dari kritik, bahkan muncul anggapan poligami di zaman sekarang sebagai bentuk eksploitasi atau kejahatan tersembunyi terhadap perempuan. ${ }^{59}$ Kejahatan yang dimaksud bisa jadi perempuan yang dinikahi sebagai istri muda layaknya seperti simpanan. Selain itu dari beberapa kenyataan menunjukkan bahwa kehidupan perempuan yang berpoligami lebih banyak mengalami kekerasan daripada kebahagiaan baik berbentuk kekerasan psikologis, fisik, ekonomi, termasuk pula kekerasan seksual. ${ }^{60}$

Menurut Guru Nursyahid ini semua karena syarat-syarat yang harus dipenuhi dalam berpoligami sudah mulai kurang diperhatikan. Oleh karena itu menurut ulama ini berdasarkan kaidah dar' al-mafäsid

\footnotetext{
${ }^{56}$ Ibid.

${ }^{57}$ Ibid.

58 Ibid.

59 Ema Khotimah, "Analisis Kritis Wacana Poligami: Praktik Marjinalisasi dan Demonologi Islam dalam Wacana Poligami”, Mediator, Vol. 9, No. 1 (Juni 2008), 190.

${ }^{60}$ Rudi Nuruddin Ambary, "Perkawinan Poligami yang Berkeadilan", al-Adalah, Vol. 11, No. 1 (2013), 75.
} 
muqaddam 'alà jalb al-mașälih, maka poligami lebih baik ditinggalkan. Pendapat yang keliru lanjut ulama ini apabila poligami dilakukan dengan cara berlindung atas nama sunat rasul, sementara di dalamnya diisi dengan perbuatan dosa yaitu diabaikannya syarat poligami yang wajib dipenuhi. ${ }^{61}$

Poligami ditinggalkan dan cukup beristri satu orang tampaknya sejalan dengan pendapat salah seorang ulama yang dikutip al-Nawawi bahwa pada masa sekarang (pada masa ulama itu) sebaiknya istri tidak lebih dari satu orang. ${ }^{62}$ Pendapat ini memberikan pemahaman bahwa kondisi -termasuk kondisi poligami di zaman Nabi Mūsā dan Nabi 'İsā yang dibahas sebelumnya- sebagaimana yang dikemukakan oleh Guru Nursyahid dapat mempengaruhi pemberlakuan suatu hukum seperti poligami. Terlebih lagi apabila hukum tersebut bukan merupakan keharusan untuk dilaksanakan dan justru adanya konsekuensi lain apabila dilakukan sebagaimana halnya poligami maka apabila melakukan praktik ini justru mendatangkan kemudaratan, tentu sebagaimana yang dikatakan Guru Nursyahid meninggalkan poligami lebih baik daripada berpoligami yang justru akan berbuat dosa.

Kendatipun di antara ulama Banjar ada pula yang menampik kemudaratan berpoligami, tetapi pada kenyataannya kemudaratankemudaratan itu ada dan terjadi pada masyarakat Muslim di zaman sekarang. Di antara kemudaratan berpoligami yang biasanya terjadi menurut Guru Husin Naparin adalah istri tua selalu teraniaya terutama secara psikologis ${ }^{63}$ dan dalam bahasa Guru Danau perilaku poligami di zaman sekarang lebih banyak menyengsarakan istri sehingga termasuk perbuatan zalim. ${ }^{64}$ Berkaitan dengan hal ini, tidak jarang timbul aspirasi dari berbagai kalangan bahwa poligami yang dilakukan tidak secara prosedural termasuk melakukan pelanggaran hukum yang layak dipidanakan. ${ }^{65}$

${ }^{61}$ Guru Nursyahid Ramli, Wawancara, Banjarmasin, 10 Desember 2015.

62 al-Nawawī, Kitāb al-Majmū', Vol. 17, 212.

63 Guru Husin Naparin, Wawancara, Amuntai-Hulu Sungai Utara, 15 Desember 2015.

${ }^{64}$ Guru Asmuni (Guru Danau), Wawancara, Danau Panggang-Hulu Sungai Utara, 14 Desember 2015

${ }^{65}$ M. Nurul Irfan, "Kriminalisasi Poligami dan Nikah Sirri”, al-'Adalah, Vol. 10, No. 2 (2011), 135. Uniknya, di samping adanya organisasi yang secara nyata menerima poligami seperti Hizbut Tahrir Indonesia (kini sudah dibubarkan Pemerintah) dan Global Ikhwan Indonesia (GII), tetapi ada juga yang menamakan dirinya sebagai 
Guru Danau mengatakan orang yang hanya memiliki satu istri saja jika berbuat zalim pada istri dipastikan berdosa, terlebih lagi bagi yang memiliki beberapa orang istri. Ia mengatakan "yang pasti mudaratnya itu menyengsarakan istri, itu zalim dia, bini saikung ja, bilang handak babaya kawa makan, handak manambah pulang lab (punya istri satu orang saja hampir tidak mampu memberikan nafkah makan, tiba-tiba ingin menambah istri), berdosa itu". ${ }^{66}$

Kemudaratan lainnya menurut guru Danau, biasanya orang yang berpoligami tidak terlepas dari dusta dan biasanya istri muda tidak selamanya mau mendampingi dan melayani suami, terlebih lagi membersihkan hajat suami ketika suami sudah tua dan sakit-sakitan. Istri tua sebaliknya, bahkan biasanya lebih dapat menerima dan memaklumi apabila ada di antara kata-kata suami yang kasar dibandingkan dengan istri muda. Ia mengatakan:

.... yang pertama bila berpoligami tu pasti badusta (berdusta), badusta lah, yang kedua, balum ada sajarah lagi bini anum mambasubi babira amun laki uyub (tidak ada sejarah istri muda membersihkan dubur setelah buang hajat ketika suami tidak memiliki kemampuan lagi), yang ketiga, bini anum amun disambat bungul tiga kali inya bulik tuh ai, bini tuba kada, hari-hari makan bungul, kada papa ai inya (kalau istri muda, dibilang bodoh kamu sebanyak tiga kali saja, ia pulang, tapi kalau istri tua, hari-hari kata-kata itu jadi makanannya, istri tua tidak apa-apa). ${ }^{67}$

Dengan berbagai kemudaratan yang disebutkan di atas, Guru Danau mengatakan walaupun memiliki kemampuan dan dapat berbuat adil sebaiknya poligami dihindari dan ditinggalkan serta cukup beristri hanya satu orang. Ia mengatakan “...yang sebaiknya jangan pang bapoligami (jangan berpoligami)... fa in lam ta'dilü fawähididah, cukup satu saja. ${ }^{68}$

Guru Danau melanjutkan, berbeda kondisinya jika poligami tersebut sangat dibutuhkan (darurat) sebagaimana yang dialami Tuan Guru Zaini Abdul Ghani. Kata Guru Danau, jaka ada anak, kada

Klub Istri Taat Suami (KITS) yang menebarkan motivasi untuk berpoligami sebagai wujud kepatuhan kepada Allah dan Rasul. Lihat dalam Slamet Firdaus, "Poligami bagi yang Mampu Monogami bagi yang tidak Mampu", al-Manabij: Jurnal Kajian Hukum Islam, Vol. 6, No. 2 (Juli 2012), 275-276.

${ }^{66}$ Guru Asmuni (Guru Danau), Wawancara, Danau Panggang-Hulu Sungai Utara, 14

Desember 2015

${ }^{67}$ Ibid.

${ }^{68}$ Ibid. 
bakun jua orang babibi lagi, mambuang-buang waktu, bahwa Tuan Guru Zaini Abdul Ghani berpoligami karena belum memiliki anak. Seandainya beliau sudah memiliki anak dipastikan tidak akan berpoligami karena berpoligami itu akan membuang-buang waktu. Guru Danau sendiri mengatakan dirinya memiliki anak sebanyak tiga belas orang, sehingga tidak ada alasan baginya untuk berpoligami. ${ }^{69}$

Gambaran kemudaratan yang diakibatkan dari perilaku orangorang yang berpoligami, telah lama terjadi dalam masyarakat Muslim. Hal ini dapat diketahui dari pendapat 'Abduh bahwa memang benar poligami pada masa-masa awal Islam sebagai solusi karena dapat mengikat hubungan keluarga dan di samping itu kesadaran beragama baik laki-laki atau perempuan masih tinggi. Namun pada masa sekarang kemudaratan itu muncul justru menimpa anak-anak, istri-istri dan kerabat yang lain sehingga menimbulkan kebencian dan permusuhan sesama mereka dari antar-anak atau antar-istri, bahkan sampai terjadi pada pembunuhan antarkeluarga yang akhirnya hubungan persaudaraan pun menjadi rusak. 'Abduh akhirnya menyeru kepada para ulama agar meresapi kembali bahwa agama diturunkan untuk kemaslahatan manusia dan sekaligus menolak segala kemudaratan. Apabila pada suatu masa lanjutnya, dalam penerapan suatu hukum terjadi suatu kemudaratan yang tidak terjadi pada masa sebelumnya maka janganlah ragu mengubah hukum tersebut untuk disesuaikan dengan keadaan sekarang berdasarkan kaidah dar' almafäsid muqaddam 'alā jalb al-masăliḥ. Oleh karena itu poligami betulbetul diharamkan ketika adanya kekhawatiran bahwa keadilan tersebut tidak dapat terlaksana. ${ }^{70}$

Pendapat di atas menunjukkan bahwa pengertian adil tersebut tidak sesederhana yang dipikirkan, melainkan sangat berhubungan dengan hal-hal lain sebagai efek poligami itu sendiri. Apakah ia menjadi solusi atau sebaliknya menimbulkan kemudaratan baik pada diri sendiri, istri pertama dan anak-anak serta istri kedua dan seterusnya bahkan dampak-dampak pada keluarga secara keseluruhan. Dengan banyaknya pertimbangan-pertimbangan tersebut maka menurut 'Abduh dan al-Marāghī kendatipun poligami itu dilakukan, tetapi syaratnya adalah dalam kondisi darurat ${ }^{71}$ sebagaimana yang

${ }^{69}$ Ibid.

${ }^{70}$ Riḍā, Tafsìr al-Manār, Vol. 4, 349-350.

71 Ibid., 350. M. Quraish Shihab menyebut poligami sebagai darurat kecil yang berbeda dari istilah ulama lainnya. Namun dilihat dari pemaknaan sepertinya 
dikemukakan ulama Banjar sebelumnya. Poligami ini baru dibolehkan kepada orang-orang yang sangat membutuhkan yang tidak ada jalan lain selain berpoligami dengan syarat dipercaya dapat berbuat adil dan diyakini pula tidak akan berbuat tidak adil. ${ }^{72}$

Berdasarkan hal demikian berarti perkawinan Islam itu pada dasarnya adalah monogami, bukan poligami. Rasulullah pun menggunakan asas monogami. Hal ini dapat dibaca dari sejarah poligami Rasulullah yang lebih singkat daripada masa monogami Rasulullah. Ketika Khadijah masih hidup Rasulullah hanya beristri Khadijah dan berkumpul dengannya kurang lebih selama dua puluh tiga tahun. Sepeninggal Khadijah Rasulullah pun baru berpoligami dan sampai wafat masa poligami yang dilewati Rasulullah kurang lebih selama delapan tahun. Hal ini menunjukkan bahwa Rasulullah sebenarnya lebih memilih beristri satu daripada berpoligami.

Dapat disimpulkan bahwa ada beberapa ulama Banjar yang menerima poligami, sebagian kecil di antaranya ada yang terkesan tidak terlalu menekankan pada persyaratan bahkan terlihat cukup longgar dan sebagian besar dari yang menerima poligami menekankan pada persyaratan yang cukup ketat bahkan sangat ketat. Maksudnya mereka baru membolehkan seseorang untuk berpoligami apabila syarat-syarat yang ditentukan yakin dapat dipenuhi. Namun ada juga di antara ulama Banjar yang terkesan menolak pemberlakuan poligami -termasuk sebagian ulama yang menerima poligami dengan berbagai persyaratan ketat cenderung menolak poligami- karena berbagai pertimbangan dan melihat pada kondisi-kondisi di zaman sekarang. Kendatipun keinginan berpoligami itu masih bisa ditolerir, disyaratkan dalam kondisi darurat.

\section{Metode Penetapan Hukum Ulama Banjar}

Perbedaan pendapat di kalangan Ulama Banjar ini tentu tidak terlepas dari perbedaan metode hukum yang digunakan. Sebagian kecil ulama Banjar yang menerima poligami yang terkesan tidak terlalu menekankan pada persyaratan tampaknya lebih banyak berpegang pada teks nass dan kurang memfokuskan pada kenyataan poligami yang terjadi pada masyarakat. Gaya berpikir dalam menetapkan

maksud Quraish Shihab ini sama dengan uraian di atas bahwa poligami hanya dilakukan di saat diperlukan dengan syarat yang tidak ringan. Lihat dalam Shihab, Wawasan Al-Quran, 200.

72 al-Marāghī, Tafsìr al-Marāghì, Vol. 4, 181. 
hukum seperti yang digambarkan di atas tampaknya lebih mendekati metode tekstual deduktif.

Adapun metode hukum ulama Banjar yang menerima poligami dengan persyaratan yang ketat tampaknya hampir tidak berbeda dengan metode hukum ulama Banjar yang terkesan menolak poligami. Gaya berpikir ulama ini tampaknya berpijak pada dasar yang sama yaitu kemaslahatan dan kemudaratan. Kendatipun terdapat perbedaan itu pun hanya pada penggunaan masing-masing kemaslahatan dan kemudaratan yang ditentukan. Ada di antaranya masih memberikan ruang dengan tetap menekankan pada syarat kelayakan untuk berpoligami dan ancaman dosa bagi yang melanggarnya serta tetap menjaga kemaslahatan seluruh keluarga. Namun justru karena kemudaratan itu ada juga yang cenderung menolak poligami diberlakukan di zaman sekarang.

Ulama Banjar dalam kategori menerima poligami dengan persyaratan yang ketat dan yang terkesan menolak poligami secara umum menjelaskan bahwa poligami di zaman sekarang (orang-orang yang melakukan praktik tersebut) cenderung banyak mendatangkan kemudaratan daripada kemaslahatan. Hal yang pasti adalah lebih banyak menyengsarakan istri baik fisik atau pun psikis serta termasuk pula dampaknya pada anak-anak. Dalam kehidupan sehari-hari secara otomatis suami tidak pernah lepas dari dusta, sementara perilaku istri muda biasanya tidak sebaik pelayanan, perlakuan dan penerimaan istri tua.

Ulama Banjar ini pun berpesan walaupun memiliki kemampuan yang cukup tetapi dengan banyaknya kemudaratan yang akan dialami, maka berdasarkan kaidah fiqh dar' al-mafäsid muqaddam 'alā jalb almasälih, mereka menegaskan poligami lebih baik ditinggalkan atau jangan berpoligami, karena termasuk perbuatan yang membuangmembuang waktu kecuali dalam keadaan darurat. Disebut demikian karena hidup hanya dihabiskan untuk mengurusi keluarga yang masing-masing memiliki kepentingan, meredam agar tidak terjadinya konflik dan akhirnya aturan-aturan Allah pun cenderung akan terlanggar. Sebagian besar ulama Banjar akhirnya bersikap apabila tidak merasa yakin dapat melakukan syarat-syarat yang ditentukan maka haram berpoligami.

Sebagaimana disebutkan sebelumnya, beberapa ulama Banjar mendasarkan pemikirannya pada kemaslahatan dan kemudaratan. Dua hal ini merupakan inti dari metode al-istihsān dan al-maslahah. Namun 
berkaitan dengan poligami yang memiliki dasar langsung dari alQur'ān dan hubungannya dengan zaman sekarang, tampaknya metode penetapan hukum yang digunakan ulama Banjar lebih dekat pada metode al-istihsān dan didukung metode al-dharī ${ }^{-} a h$.

\section{Analisis Poligami Perspektif Istihsān}

Di antara makna al-istibsān adalah mengamalkan di antara dua dalil yang lebih kuat atau meninggalkan suatu ketentuan hukum kepada ketentuan hukum lain yang lebih kuat dari ketentuan hukum sebelumnya. Ditinggalkannya suatu ketentuan ini dipastikan memiliki alasan yang jelas dan kuat, sebab tidak mungkin suatu ketentuan ditinggalkan yang kemudian melaksanakan ketentuan lain apabila hanya untuk kepentingan sesaat atau kelompok dan individu, terlebih untuk menimbulkan kemudaratan pada orang lain. Dipastikan proses ini dilakukan untuk mendatangkan atau memelihara kemaslahatan yang universal dan menolak kemudaratan yang akan menimpa masyarakat Islam secara luas.

Ada beberapa model al-istihsān yang dapat digunakan untuk mengkaji hukum poligami. Di antara model tersebut adalah melalui proses al-istiḩān bi al-nașs yaitu ber-istibsān dengan ayat atau hadīth. Maksudnya suatu ketentuan dalam suatu ayat atau hadīth tidak diamalkan karena adanya ketentuan lain baik ayat atau hadīth yang dipandang tepat dan kuat untuk diamalkan. Dalam hal ini al-Qur'àn, 4: 3 tentang bolehnya berpoligami sampai empat orang istri ditinggalkan untuk mengamalkan al-Qur'ān 4: 129 tentang ketidakmungkinan berbuat adil walaupun masing-masing menghendaki. Kendatipun al-Qur'ān 4: 129 berkaitan dengan keadilan rasa cinta yang tidak disyaratkan, ${ }^{73}$ tetapi bermula dari ketidakadilan cinta itulah membuat tidak adil dalam hal lain. ${ }^{74}$ Akhirnya apabila terjadi kemudaratan dalam poligami, menunjukkan bahwa suami (ayah) tidak mampu melindungi keluarga dan ia sendiri pun tampaknya tidak dapat

\footnotetext{
73 Ibid., Vol. 5, 172-173. Kendatipun demikian janganlah menampakkan kecenderungan itu secara berlebihan sehingga menimbulkan keburukan pada istriistri yang lain terlebih lagi membuat mereka merasa terkatung-katung. Lihat Ibn 'Ashūr, Tafsìr al-Taḥrì, Vol. 5, 218. Namun dalam pendapat Mujahid bahwa kewajiban adil pada al-Qu'an, 4: 129 tidak hanya dalam membagi waktu dan memberikan nafkah tetapi adil juga dalam masalah cinta (rasa). Lihat al-Qurțūbī, alJāmi'li Aḅkàm, Vol. 7, 168.

74 al-Jawzī, Zäd al-Masir, 332.
} 
menjadi panutan. Berdasarkan hal ini Al-Qur'ān, 4: 129 lebih utama diperhatikan daripada al-Qur'ān, 4: 3 karena di dalamnya terdapat pernyataan langsung dari Allah bahwa sampai kapanpun para suami tidak akan dapat berbuat adil kepada istri-istrinya. Pernyataan ini pada hakikatnya menunjukkan bahwa Allah pun tidak menghendaki praktik poligami ini terjadi terlebih lagi pada zaman sekarang.

Begitu juga mesti pula dikaitkan dengan al-Qur'ān, 4: 9 tentang pentingnya setiap orang tua (suami) terlebih bagi yang berpoligami merasa khawatir jika mereka meninggalkan (wafat) anak-anak dalam keadaan lemah baik lemah secara pendidikan, ekonomi dan lemah dari segi lainnya. Kekhawatiran ini penting ada pada setiap suami karena anak dan istri merupakan tanggung jawabnya di kehidupan dunia dan akan diminta pertanggungjawaban di akhirat kelak. Hal ini dikuatkan pula sebagaimana dalam al-Qur'ān, 8: 28 dan 64: 15 bahwa istri dan anak-anak disebut sebagai cobaan yang kelak suami akan diminta pertanggungjawabannya di hadapan Allah. Betapa hal ini sangat memberikan kemudaratan jika yang melakukan poligami adalah seorang yang tidak memiliki kemampuan dan tidak bertanggung jawab serta bahkan tidak layak untuk berpoligami baik karena tidak mencukupi syarat atau karena hanya untuk kesenangan.

Model al-istihsān berikutnya yang dapat digunakan untuk mengkaji hukum poligami adalah al-istihsān bi al-maslạ̣ah yaitu ber-istihsān dengan al-maslaḥah. Maksudnya al-Qur'ān, 4: 3 tentang bolehnya berpoligami sampai empat orang istri ditinggalkan atau tidak diberlakukan karena timbulnya berbagai kemudaratan pada institusi keluarga. Kemudaratan-kemudaratan tersebut telah disebutkan beberapa ulama Banjar sebelumnya yang seperti itulah yang terjadi pada saat ini.

Dalam salah satu kaidah fiqh disebutkan al-darar yuāa $l^{75}$ bahwa kemudaratan itu mesti dihilangkan maka jalan yang harus ditempuh untuk menghilangkan kemudaratan tersebut adalah dengan cara melarang poligami. Diakui kemudaratan itu tidak dapat dihilangkan secara seratus persen, tetapi upaya maksimal mesti dilakukan untuk menghilangkan kemudaratan tersebut sebagaimana kaidahal-darar yudfa bi-qadr al-imka $\bar{n}^{76}$ bahwa kemudaratan itu mesti ditolak atau dihilangkan secara semaksimal mungkin. Di sini yang diharapkan

\footnotetext{
${ }^{75}$ Muhammad 'Uthmān Shibīr, al-Qawāid al-Kullìyah wa al-D awābit al-Fiqhīyah fi alSharīah al-Islāmìyah (Yordania: Dār al-Nafā'is, 2006), 163.

${ }^{76}$ Ibid., 184.
} 
bukan hanya sekadar berakhir pada dakwah bahasa lisan, tetapi mestinya dilakukan dan dipraktikkan. Orang yang mempraktikkan terlebih dahulu adalah para ulama, terlebih lagi para ulama yang dapat berkomunikasi dengan masyarakat secara lebih luas, sehingga dari ajakan dan praktik yang dilakukannya akan diikuti masyarakat karena mereka adalah contoh dan teladan masyarakat Muslim.

Mempertahankan dan mempraktikkan secara terus menerus praktik poligami sama artinya mengekalkan kemudaratan dan hal ini sebenarnya tidak diinginkan dalam Islam sebagaimana dalam salah satu kaidah al-darar là yakēnu qadiman ${ }^{77}$ bahwa kemudaratan itu tidak bisa didiamkan terus menerus karena dipandang telah lama terjadi. Membiarkan kemudaratan terjadi terus menerus sama artinya membiarkan masyarakat Islam selalu berbuat kemudaratan.

Larangan berpoligami merupakan suatu kemaslahatan atau kebaikan pada keluarga karena memelihara keutuhan rumah tangga adalah wajib dilakukan setiap orang. Oleh karena itu melalui proses alistibsān bi al-maslahah poligami tidak dibolehkan lagi untuk menjaga kemaslahatan rumah tangga yang telah dibina. Anak-anak dan istri pun dapat diperhatikan secara maksimal dan dapat melahirkan generasi yang berkualitas karena waktu dapat difokuskan untuk membimbing keluarga.

Diakui dalam al-Qur'ān, 4: 3 poligami dibolehkan, tetapi jika kembali pada aturan yang terdapat pada kaidah mubāh bahwa pada hakikatnya mubāh tidak selamanya berlaku secara mutlak, sebaliknya terkadang ia berubah menjadi wajib dan terkadang pula berubah menjadi haram. ${ }^{78} \mathrm{Hal}$ ini menunjukkan bahwa poligami tergantung dengan konteks dan permasalahan yang dihadapi. Contoh dalam referensi Islam klasik darah setiap manusia haram sehingga wajib dijaga, tetapi di suatu saat ada salah seorang Muslim yang murtad sehingga darahnya pun menjadi halal.

Konteks permasalahan tampaknya dapat mengubah suatu ketentuan yang asalnya diharamkan dapat berubah menjadi dihalalkan dan begitu pula sebaliknya. Hukum poligami pun dapat menerapkan ketentuan di atas, yang asalnya dibolehkan (mubāha) tetapi karena kondisi saat ini berbeda dengan zaman nabi bahwa poligami bukan lagi dipandang menjadi solusi tetapi banyak menimbulkan

77 Ibid., 186.

${ }^{78}$ Abū Zahrah, Ușūl al-Fiqh (Kairo: Dār al-Fikr al-'Arabī, t.th), 38. 
kemudaratan maka ke-mubāh-an poligami berubah menjadi perbuatan yang dilarang.

\section{Analisis Poligami Perspektif al-Dharīah}

Metode al-dhari'ah ini digunakan beberapa ulama Banjarwalaupun tidak secara tegas menyebut nama metode tersebut-dalam menjelaskan hukum poligami. Hal ini terlihat ketika beberapa ulama Banjar mengatakan bahwa dengan beragamnya perilaku orang-orang yang berpoligami yang cenderung tidak memperhatikan lagi syaratsyarat yang ditentukan, poligami pada zaman sekarang lebih banyak membawa kepada kemudaratan. Perkataan ini menunjukkan bahwa poligami merupakan wasilah atau media yang dapat mengantarkan pada suatu tujuan.

Tujuan ini tentu sudah pasti berkaitan dengan motif-motif yang membuat orang termotivasi melakukannya. Ada yang melakukan poligami karena belum sama sekali memiliki keturunan sementara ingin memiliki keturunan sendiri dan usia pun sudah semakin tua sehingga dikhawatirkan tidak sempat memiliki keturunan sendiri, sementara dari hasil diagnosa dokter istri tidak memungkinkan untuk memberikan keturunan baik karena mandul atau penyakit lainnya yang tidak dapat melayani suaminya. ${ }^{79}$

Ada juga yang bertujuan untuk mengangkat harkat dan martabat seorang perempuan miskin, yatim atau sebagaimana yang diharuskan oleh Muḥammad Shaḥrūr bahwa poligami dibolehkan asalkan istri kedua, ketiga dan keempat adalah perempuan janda yang memiliki anak sehingga anak-anak yatim itu terayomi oleh suami baru ibu mereka (ayah tiri). ${ }^{80}$ Namun ada juga yang tidak dapat diidentifikasi tujuannya karena motifnya hanya ingin menambah istri. Jelasnya

79 Dalam Undang-Undang Nomor 1 Tahun 1974 pasal 3 dan 4 bahwa pada dasarnya perkawinan adalah berasas monogami, tetapi dalam keadaan tertentu suami diizinkan untuk beristri kembali apabila istri tidak dapat menjalankan kewajibannya sebagai istri, cacat badan atau penyakit yang tidak dapat disembuhkan atau tidak dapat melahirkan keturunan. Aturan di atas kemudian disusun kembali khusus untuk masyarakat Islam yaitu dengan terbitnya Instruksi Presiden RI Nomor 1 Tahun 1991 tentang Kompilasi Hukum Islam pada pasal 55-59. Lihat dalam Departemen Agama RI, Bahan Penyuluban Hukum, 117-118 dan 176-177.

80 Muhammad Shahrūr, al-Kitāb wa al-Qur'àn: Qiräàh Mu'ạsarab (Damaskus-Suriah: al-Ahālī, t.th.), 599. Lihat juga pemikiran yang sama dalam karyanya yang lain yaitu Muhạmmad Shahrūr, Naḥw Ușül Jadìdah li Fiqh al-Islämi: Fiqh al-Mar'ah (DamaskusSuriah: al-Ahālī, 2000), 303. 
setiap orang yang berpoligami dipastikan memiliki tujuan-tujuan tertentu. Hal ini sesuai dengan salah satu kaidah fiqh al-umür bimaquasidiha $\bar{a}^{81}$ yaitu setiap sesuatu sesuai dengan tujuannya. Tujuantujuan ini di samping hanya yang bersangkutan dan Allah mengetahuinya juga dapat dibaca melalui indikasi-indikasi yang tampak.

Jika mengikuti alur kerja al-dhari ah sebagai media, poligami juga dipastikan dapat mengantarkan kepada kebaikan atau kepada keburukan. Apabila dapat membawa kepada kebaikan sebagaimana beberapa tujuan yang disebutkan di atas maka poligami dibolehkan, terlebih lagi apabila poligami ini secara benar dapat membawa kepada kebahagiaan dan memperkuat keutuhan rumah tangga maka tidak hanya dibolehkan melainkan wajib dilakukan (fath al-dhari'ah). Hal ini sesuai dengan kaidah mā là yatimmu al-wäjì illā bih fahuwa wajijib bahwa keutuhan rumah tangga tidak akan dapat tercapai kecuali melalui poligami maka poligami pun menjadi wajib. Di samping melalui pandangan tersebut, tentunya juga harus dipelajari melalui proses yang objektif yang melibatkan paramedis dan juga pengadilan.

Namun sebaliknya apabila tujuan itu tidak dapat diidentifikasi dan cenderung hanya ingin menambah istri karena semata-mata memiliki kekayaan maka persoalan ini mesti pula diukur secara objektif terutama melalui proses pengadilan. Jika terdapat kebaikan, praktik ini dibolehkan tetapi jika akan menimbulkan kemudaratan, poligami tidak dibolehkan bahkan diharamkan (sadd al-dhari'ab) sebagaimana kaidah $m \bar{a}$ addā ilā al-harām fabuwa harām. ${ }^{83}$ Adapun poligami yang dilakukan tidak melalui proses persidangan dipandang sebagai poligami tidak tercatat yang hukumnya sama dengan akad nikah tidak tercatat yang tidak memiliki kekuatan hukum tetap.

Jelasnya apabila ingin mengetahui kemungkinan-kemungkinan yang dapat terjadi pada poligami apakah termasuk fath al-dhari'ah atau sadd al-dhari ah, hal yang mesti dilakukan adalah pertama, melihat tujuan yang telah direncanakan sebagai target pencapaian, kedua, proses

${ }^{81}$ Jalāl al-Dīn 'Abd al-Raḥmān al-Suyūṭī, al-Ashbāh wa al-Nazaàìr (Beirut: Dār alKutub al-'Ilmīyah, 1983), 8. Zayn al-Dīn b. Ibrāhīm b. Muhammad b. Najīm, alAshbāh wa al-Nažàir 'alā Madhhab Abì Hẹaîfah al-Nu'mān (Beirut: Dār al-Kutub al'Ilmiyah, 1999), 23.

82 Tāj al-Dīn 'Abd al-Wahhāb b. 'Alī b. 'Abd al-Kāfi al-Subkī, al-Ashbāh wa alNažāir, Vol. 2 (Beirut: Dār al-Kutub al-'Ilmīyah, 1991), 88.

83 A. Djazuli dan I. Nurol Aen, Ushul Figh Metodologi Hukum Islam (Jakarta: Raja Grafindo Persada, 2000), 32. 
pelaksanaan al-dhari'ah tersebut dan ketiga hasil (al-natijah) dari pelaksanaan al-dhari $a b$. Ketiga macam ini mesti dilihat sebagai satu kesatuan integratif yang tidak terpisahkan. Orang yang ingin berpoligami mesti mempelajari tujuan berpoligami dan agar mendapatkan tujuan yang jelas serta objektif mesti melalui proses persidangan. Setelah tujuan yang dimaksud dapat dilacak, poligami dilangsungkan mesti secara tercatat agar legalitas dan kepastian hukum poligami dapat diakui. Terakhir adalah mempelajari hasil (al-natijah) dari pelaksanaan poligami dan hal ini dapat dipelajari melalui faktafakta atau pengalaman-pengalaman yang terjadi pada masyarakat yang berpoligami selama ini.

Apabila ketiga proses di atas dapat dipenuhi dan khususnya melalui hasil kajian baik secara teori ataupun dukungan dari fakta di lapangan poligami yang dilakukan berbuah (al-natijah) kemaslahatan, maka pelaksanaan poligami dapat dilakukan. Namun apabila al-natijah dari poligami yang dipelajari melalui penelitian-penelitian berdampak buruk atau mendatangkan kemudaratan maka berdasarkan kaidah dar' al-mafäsid muqaddam 'alā jalb al-mașälì, poligami pun tidak dibolehkan.

Diakui kondisi setiap orang berbeda, ada yang merasa mendapatkan kemaslahatan tetapi sangat banyak mendapatkan kemudaratan. Untuk menghadapi persoalan ini dipastikan harus memilih apakah mengambil kemaslahatan atau tetap menolak kemafsadatan. Dalam kaidah fiqh disebutkan apabila terjadinya pertentangan antara kemaslahatan dan kemudaratan maka yang harus didahulukan adalah menolak kemudaratan. ${ }^{85}$ Berarti dilarangnya poligami adalah hal yang lebih utama untuk didahulukan. Kendatipun dampak pada masing-masing orang berbeda, tetapi untuk memelihara stabilitas institusi keluarga secara umum, poligami pun dilarang sekalipun memiliki kemampuan dan berkedudukan sebagai ulama, kecuali dalam keadaan darurat.

Darurat merupakan suatu kondisi yang tidak ditemukan jalan lain selain melakukan jalan yang dilarang. Poligami pada awalnya dibolehkan tetapi karena banyaknya kemudaratan, menurut kajian ini poligami pun dilarang kecuali tidak ditemukan jalan lain selain melakukan poligami. Hal ini sesuai dengan kaidah bahwa kemudaratan membolehkan perbuatan yang dilarang. ${ }^{87}$

\footnotetext{
85 al-Suyūtī, al-Ashbāh wa al-Nazāöir, 87.

${ }^{87}$ Dalam al-Suyūṭi kaidah di atas tertulis al-darūrȳyàt. Lihat al-Suyūṭin, al-Ashbāh wa alNazāir, 23.
} 
Namun ada syarat-syarat khusus agar suatu keadaan tersebut dapat diterima sebagai keadaan darurat. Syarat-syarat tersebut pertama, hal yang termasuk darurat adalah berkaitan dengan perkara primer (usūl al-khamsah dalam maqāsid al-sharïah) yang apabila tidak melakukan hal darurat tersebut dapat mengakibatkan kecacatan bahkan kematian, kedua, nyatanya keterpaksaan untuk melakukan hal yang dilarang, ketiga, melakukan hal yang dianggap darurat sebatas yang dibolehkan sampai ukuran yang dipandang cukup untuk tidak lagi disebut masa darurat, keempat, kemudaratan yang timbul sebagai akibat dari melakukan hal yang darurat itu lebih kecil daripada kemudaratan yang awal darurat itu muncul, kelima, tidak termasuk pada prinsip-prinsip umum yang berkaitan dengan penegakan keadilan, hak asasi, atau masalah akidah, keenam, adanya peran pemerintah dalam menentukan hal-hal yang disebut darurat dan ketujuh, waktu yang diberikan sebatas masa darurat. ${ }^{88}$

Apabila ketujuh syarat di atas dapat dipenuhi maka poligami dapat dibolehkan. Poligami merupakan solusi bagi orang-orang yang memiliki keterpaksaan-keterpaksaan seperti yang dideskripsikan. Hal ini tidak hanya membawa kepada kemaslahatan yang bersangkutan tetapi membawa kebaikan pula kepada seluruh keluarga yang dengan poligami ini keutuhan rumah tangga menjadi terjaga.

\section{Penutup}

Ada beberapa ulama Banjar yang menerima poligami, sebagian kecil di antaranya ada yang terkesan tidak terlalu menekankan pada persyaratan bahkan terlihat cukup longgar dan sebagian besar dari yang menerima poligami menekankan pada persyaratan yang cukup ketat bahkan sangat ketat. Namun ada juga di antara ulama Banjar yang terkesan menolak pemberlakuan poligami-termasuk sebagian ulama yang menerima poligami dengan berbagai persyaratan ketat cenderung menolak poligami- karena berbagai pertimbangan dan melihat pada kondisi-kondisi di zaman sekarang. Kendatipun keinginan berpoligami itu masih bisa ditolerir, disyaratkan dalam kondisi darurat.

Perbedaan yang terjadi di antara ulama Banjar, tentu tidak terlepas dari perbedaan metode hukum yang digunakan. Ada yang terkesan hanya berpegang pada teks naș (tekstual deduktif), ada juga yang

88 Shibīr, al-Qawāid al-Kullìyah, 214-215. Secara umum syarat-syarat darurat ini juga

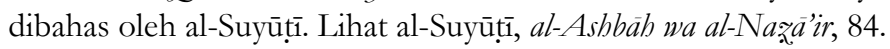


berpegang pada teks nas tetapi tetap memperhatikan kondisi kekinian, sehingga gaya berpikir yang digunakan pun cenderung kontekstual empiris dengan berpijak pada kemaslahatan dan kemudaratan. Jika dikaitkan dengan ilmu ușül al-fiqh maka berdasarkan dari pijakan di atas khususnya berkaitan dengan poligami, metode hukum yang digunakan ulama Banjar lebih cenderung menggunakan metode alistihsān dan al-dharíah.

\section{Daftar Rujukan}

Ambary, Rudi Nuruddin. "Perkawinan Poligami yang Berkeadilan", al-'Adalah, Vol. 11, No. 1. 2013.

'Arabī (al), Ibn. Aḅkām al-Qur'ān, Vol. 1. Beirut: Dār al-Kutub al'Ilmìyah, t.th.

'Ashūr, Muḥammad Tāàir b. Tafsìr al-Taḥrìr wa al-Tanwìr, Vol. 4. Tunisia: Dār al-Tūnisiah, 1984.

Asmuni, Guru (Guru Danau). Wawancara. Danau Panggang-Hulu Sungai Utara, 14 Desember 2015.

Azdī (al), Abū Dāwd al-Shi'ath al-Sijsītānī. Sunan Abì Dāwod, Vol. 4. Beirut: Dār Ibn Hạam, 1997.

Bakhiet, Guru Muhammad. Wawancara. Kitun-Barabai, 13 Desember 2015.

Bayjūrī (al), Ibrāhīm. Hạshiyat al-Shaikh Ibrāhim al-Bayjūrì 'alā Sharḅ al'Allämah ibn Qäsim al-Ghazæì 'alā Matn al-Sheikh Abi Shujā', Vol. 2. Beirut: Dār al-Kutub al-'Ilmīyah, 1999.

Bukhārī (al), Abū 'Abd al-Lāh b. Muhammad Ismāî̀l. Șah̄ị al-Bukhārì, Vol. 1. Beirut-Damaskus: Dār Ibn Kathīr, 1993.

Departemen Agama RI. Bahan Penyuluban Hukum. Jakarta: Dirjen Bimbingan Masyarakat Islam dan Penyelenggaraan Haji, 2004.

Djazuli, A. dan Aen, I. Nurol. Ushul Figh Metodologi Hukum Islam. Jakarta: Raja Grafindo Persada, 2000.

Djunaidi, Ustazah Habibah. Wawancara. Banjar Baru, 31 Agustus 2016.

Firdaus, Slamet. "Poligami bagi yang Mampu Monogami bagi yang tidak Mampu", al-Manahij: Jurnal Kajian Hukum Islam, Vol. 6, No. 2, Juli 2012.

Hasbi, Guru Zarkasyi. Wawancara. Cindai Alus-Martapura, 11 Desember 2015.

Imron HS, Ali. "Menimbang Poligami dalam Hukum Perkawinan", Jurnal Ilmiah Ilmu Hukum QISTI, Vol. 6, No. 1, Januari 2012. 
Irfan, M. Nurul. "Kriminalisasi Poligami dan Nikah Sirri”, al-'Adalah, Vol. 10, No. 2, 2011.

Jawzī (al), Jamāl al-Dīn 'Abd al-Raḥmān b. 'Alī b. Muḥammad. Zād alMasì fì Tlm al-Tafsìr. Beirut: Dār Ibn Hazm, 2002.

Khotimah, Ema. "Analisis Kritis Wacana Poligami: Praktik Marjinalisasi dan Demonologi Islam dalam Wacana Poligami”, Mediator, Vol. 9, No. 1, Juni 2008.

Marāghī (al), Aḥmad Muștafā. Tafsìr al-Maräghì, Vol. 4. Mesir: alMuṣtafā al-Bāb al-Halabīi, 1946.

Musarrofa, Ita. "Poligami: antara Legalitas Formal dan Legalitas Budaya: Studi Kasus Praktik Poligami Kyai Pesantren di Probolinggo Jawa Timur", al-Mawarid: Journal of Islamic Law, Vol. 14, 2005.

Nadhiroh, Wardatun. "Poligami Tuan Guru: Analisis atas Budaya Perempuan 'Basurung' di Banjar' dalam http://idr.uinantasari.ac.id/6427/

Najīm, Zayn al-Dīn b. Ibrāhīm b. Muhammad b. al-Ashbāh wa alNazāìir 'alā Madhhab Abì Hẹañfah al-Nu'mān. Beirut: Dār al-Kutub al-'Ilmìyah, 1999.

Naparin, Guru Husin. Wawancara. Amuntai-Hulu Sungai Utara, 15 Desember 2015.

Naupal, Guru Muhammad. Wawancara. Martapura, 30 Agustus 2016.

Nawawī (al), Abū Zakarīyā Muh al-Dīn b. Sharf. Kitāb al-Majmū' Sharḥ al-Mubadhdhab li Shayrāż̀, Vol. 17. Jeddah: Maktabat al-Irshād, t.th. Qazwīnī (al), Abū 'Abd al-Lāh Muḥamad b. Yazīd. Sunan Ibn Mājah, Vol. 1. t.t.: Dār Ihyāa al-Kutub al-'Arabīyah, t.th.

Qurțūbī (al), Abū Bakr. al-Jāmi‘ li Ạ̣keàm al-Qur'ān, Vol. 6. Beirut: Mu'assasat al-Risālah, 2006.

Ramli, Guru Nursyahid. Wawancara. Banjarmasin, 10 Desember 2015.

Riḍā, Muḥammad Rashīd. Tafsìr al-Manār, Vol. 4. Kairo: Dār alManār, 1947.

Rinawati, Rini. "Dramaturgi Poligami”, Mediator, Vol. 7, No. 1, Juni 2006.

Sābiq, Sayyid. Fiqh al-Sunnah, Vol. 2. Kairo: al-Fatḥ li I'lām al-'Arabī, 1995.

Shahrūr, Muhammad. al-Kitāb wa al-Qur'àn: Qiräả Mu'ăsarah. Damaskus-Suriah: al-Ahālī, t.th. 
----. Naḥw Ușül Jadidah li Fiqh al-Islämi: Fiqh al-Mar'ah. DamaskusSuriah: al-Ahālī, 2000.

Sharfī (al), 'Abd al-Majīd al-Sawsūh. al-Ijtihāed al-Jamā̄ồ fì al-Tashrì' alIslāmì. Qatar: Wuzārat al-Awqāe li al-Shu'ūn al-Islāmiyah, 1998.

Shibīr, Muhammad 'Uthmān. al-Qawāìd al-Kullīyah wa al-Dawāabit alFiqhiyah fi al-Sharīa ab al-Islämìyah. Yordania: Dār al-Nafā'is, 2006.

Shihab, M. Quraish. Membumikan Al-Quran. Bandung: Mizan, 1996.

----. Wawasan Al-Quran. Bandung: Mizan, 1999.

Subkī (al), Tāj al-Dīn 'Abd al-Wahhāb b. 'Alī b. 'Abd al-Kāfi. alAshbāh wa al-Nazăàir, Vol. 2. Beirut: Dār al-Kutub al-'Ilmìyah, 1991.

Surie, Guru Supian. Wawancara. Pamangkih-Barabai, 12 Desember 2015.

Suyūṭī (al), Jalāl al-Dīn 'Abd al-Raḥmān. al-Ashbāh wa al-Naz̧āir. Beirut: Dār al-Kutub al-'Ilmīyah, 1983.

Zahrah, Abū. Ușül al-Fiqh. Kairo: Dār al-Fikr al-'Arabī, t.th.

Zuhaylī (al), Wahbah. al-Figh al-Islami wa Adillatuh, Vol. 7. DamaskusSuriah: Dār al-Fikr, 1985. 